DOI: $10.4274 /$ tpa.45.353

\title{
Lenfoma ve solid tümörlü çocuklarda febril nötropeni: Tek merkez deneyimi
} Febrile neutropenia in children with lymphoma and solid tumors: One center experience

\author{
Metin Demirkaya*, Taner Özgür, Solmaz Çelebi* ${ }^{*}$, Betül Sevinir* ${ }^{*}$ Mustafa Hacımustafaoğlu** \\ Uludağ Üniversitesi Tıp Fakültesi, Çocuk Sağlı̆ıı ve Hastalıkları Anabilim Dalı, Bursa, Türkiye \\ *Uludağ Üniversitesi Tıp Fakültesi, Çocuk Sağlığı ve Hastalıkları Anabilim Dalı, Çocuk Onkoloji Bilim Dalı, Bursa, Türkiye \\ * *Uludağ Üniversitesi Tıp Fakültesi, Çocuk Sağlığı ve Hastalıkları Anabilim Dalı, Çocuk Enfeksiyon Bilim Dalı, Bursa, Türkiye
}

\section{Özet}

Amaç: Merkezimizde tedavi edilen kanserli çocuklardaki febril nötropeni ataklarının değerlendirilmesidir.

Gereç ve Yöntem: Ocak 2000-Aralık 2005 tarihleri arasında febril nötropeni tanısı ile hastaneye yatırılan 57 lenfoma ve solid tümörlü hastada 206 febril nötropeni atağı geriye dönük olarak incelendi.

Bulgular: Febril nötropeni atağı sırasında bakılan ortalama mutlak nötrofil sayısı (MNS) 296 $\pm 342 / \mathrm{mm}^{3}$, mutlak lenfosit sayısı (MLS) $518 \pm 896 / \mathrm{mm}^{3}$, mutlak monosit sayısı (MMS) $144 \pm 262 / \mathrm{mm}^{3}$, C-reactive protein (CRP) $7,63 \pm 7,06 \mathrm{mg} / \mathrm{dL}$, ateş $38,5 \pm 0,2^{\circ} \mathrm{C}$ olarak bulundu. Atakların \%57,3'ünde enfeksiyon odağı yoktu. Saptanan odaklar arasında en sık farenjit \%14 ve mukozit \%12,1 görüldü. Atakların \%87,8'inde üçüncü kuşak sefalosporin ve aminoglikozid birlikte uygulandı. Kan kültürlerinin \%14,6'sında üreme görüldü. Üreyen etkenler arasında gram negatif bakteriyemi oranı yüksekti (\%60). En sık üreyen etkenler E.coli $(\% 16,7)$, Enterobacter cloaca (\%13,3), S.epidermidis $(\% 13,3)$ olarak bulundu. Ampirik tedavi başarı oranı \%67,5 saptandı. Tanı anındaki enfeksiyon odağı, MNS, MMS, CRP ile bakteriyemi arasında ilişki saptanmadı. Atak sırasında mukozit varlığının yatış süresini anlamlı olarak uzattığı görüldü. Tedavi rejimleri arasında tedavi başarısı, bakteriyemi ve yatış süresi açısından anlamlı fark saptanmadı. Nötropeni süresinin nöroblastom ve beyin tümörleri grubunda daha uzun olduğu saptandı. Ölüm oranı \%1,45 idi.

Çıkarımlar: Enfeksiyon etkenlerinin üretilme oranı düşük olan çalışmamızda gram negatif bakteriyemi oranı daha yüksekti. Gram pozitif bakteriyemi oranının düşük olmasının nedeninin hiçbir hastada santral venöz kateter kullanılmamasına bağlı olduğu düşünüldü. Körlemesine tedavide sefalosporin ve aminoglikozidin birlikte kullanılması ile başarı oranı yüksek ve ölüm oranı düşüktü. (Türk Ped Arş 2010; 45: 353-8)

Anahtar sözcükler: Çocuk, kanser, febril nötropeni

\section{Summary}

Aim: The objective of this study is to evaluate the febrile neutropenia attacks in the children who have been treated for cancer in our center.

Material and Method: Between January 2000 and December 2005, 57 patients with lymphoma and solid organ tumors who, had a total of 206 attacks of febril neutropenia were evaluated retrospectively.

Results: The mean absolute neutrophil count (ANC), absolute lymphocyte count (ALC), absolute monocyte count (AMC) levels at the time of febril neutropenia attacks were $296 \pm 342 / \mathrm{mm}^{3}, 518 \pm 896 / \mathrm{mm}^{3}, 144 \pm 262 / \mathrm{mm}^{3}$, respectively. The mean C-reactive protein (CRP) level was $7.63 \pm 7.06 \mathrm{mg} / \mathrm{dL}$, Hb level was $8.67 \pm 1.74 \mathrm{~g} / \mathrm{dL}$ and fever was $38.5 \pm 0.2^{\circ} \mathrm{C}$. There were no infection focus in the $57.3 \%$ of the attacks $(n=118)$ and the most common infection focuses were pharyngitis and mucositis and they were seen in the $14 \%$ and $12.1 \%$ of the attacks, respectively. Combination of third generation cephalosporins and aminoglycosides were given in $87.8 \%$ ( $n=181)$ of the attacks. Bacteremia was found in $14.6 \%(n=30)$. The rate of isolated gram negative bacteria $(60 \%)$ was higher than the others. The most common agents isolated were E.coli, Enterobacter cloaca and S.epidermidis in $16.7 \%, 13.3 \%$ and $13.3 \%$, respectively. The success rate of therapy was found as $67.5 \%$. There were no correlations between the infection focus and AMC, ANC, CRP levels, and mucositis and bacteremia. The presence of mucositis prolonged the duration of hospitalization. There were no significant differences between therapy regimens according to success of therapy, bacteremia and duration of hospitalization. The duration of neutropenia was longer in neuroblastoma and brain tumors. The mortality rate was found as $1.45 \%$.

Conclusions: The rate of gram negative bacteremia was higher in our study. None of our patients had central venous catheters, so we thought that this could be the reason to the lower rate of isolated gram positive bacteria. The response rate to the treatment was good and mortality rate was low with the empirical treatment by cephalosporin and aminoglycoside combination. (Turk Arch Ped 2010; 45: 353-8)

Key words: Child, cancer, febrile neutropenia

Yazışma Adresi/Address for Correspondence: Dr. Metin Demirkaya, Uludağ Üniversitesi Tıp Fakültesi, Çocuk Sağlığı ve Hastalıkları Anabilim Dalı, Çocuk Onkoloji Bilim Dall, 16059, Görükle, Bursa, Türkiye E-posta: demirkayametin@hotmail.com Geliş Tarihi/Received: 15.02.2010 Kabul Tarihi/Accepted: 25.05.2010 


\section{Giriş}

Son yıllarda çocukluk çağı kanserlerinin seyirlerinde belirgin bir iyileşme olmakla beraber, bu hastalarda enfeksiyonlar önemli bir hastalık ve ölüm nedenidir (1-3). Geçen sürede bulunan çok sayıda yeni antibiyotiğe ve destek tedavilerindeki büyük gelişmelere karşın son yıllarda daha yoğun kemoterapi yöntemlerinin kullanımı hastalanma ve ölüm oranlarında artışa neden olmaktadır.

Mutlak nötrofil sayısının (MNS) 500/ $\mathrm{mm}^{3}$ 'ün altında olduğu veya MNS'nin 500-1000/mm³ arasında olup, takip eden 24-48 saat içinde $500 / \mathrm{mm}^{3}$ 'ün altına düşme ihtimali yüksek olan hastalar nötropenik olarak değerlendirilmektedir. Amerikan Enfeksiyon Hastalıkları Derneği febril nötropeniyi, nötropeni eşliğinde, ağızdan bir kez $38,3^{\circ} \mathrm{C}$ 'nin üstünde veya bir saatten uzun süren $38^{\circ} \mathrm{C}$ ateş saptanması olarak tanımlamaktadır. Ateş olmadığı halde, fokal veya sistemik enfeksiyon bulgu ve belirtilerinin olduğu (şiddetli karın ağrısı, ciddi mukozit, rektal apse, klinik sepsis, şok) durumlarda nötropenik hasta, febril nötropeni kapsamında ele alınır. Bir haftadan uzun süreli nötropenili olguların tama yakınında enfeksiyon gelişmektedir. Febril nötropenide ölüm oranları nötropeninin derinliğiyle ilişkilidir (1-4,5).

Son yıllarda febril nötropeni ataklarında gram pozitif etkenler ön plandadır, ancak ciddi enfeksiyonlardan gram negatif etkenler sorumludur. Saptanabilen en sık gram pozitif mikroorganizmalar koagülaz negatif stafilokoklar (KNS), S.aureus ve alfa hemolitik streptokoklardır. En sık üretilen gram negatif etkenler ise Pseudomonas aeroginosa, Escherichia coli ve Klebsiella pneumoniae'dır (3,6-9).

Bu çalışmada, Uludağ Üniversitesi Tıp Fakültesi Çocuk Onkoloji Bilim Dalı'nda takip ve tedavi edilen kanserli çocuklarda 2000-2005 yılları arasında gelişen febril nötropeni ataklarının değerlendirilmesi amaçlanmaktadır.

\section{Gereç ve Yöntem}

Veriler, Uludağ Üniversitesi Tıp Fakültesi Çocuk Onkoloji Bilim Dalı'nda takip edilen ve 01.01.2000-31.12.2005 tarihleri arasında febril nötropeni tanısı ile yatırılarak tedavi edilen hastaların dosyalarından elde edildi.

Hastaların dosya kayıtlarından; yașı, cinsiyeti, tanısı, hastalığın evresi, kemoterapi sonrası geçen süre, ateş varlığı, ateş süresi, nötropeni süresi; tanıda ve izlemde MNS, mutlak lenfosit sayısı (MLS), mutlak monosit sayısı (MMS), hemoglobin, trombosit, C-reaktif protein (CRP) değerleri; idrar tetkiki, enfeksiyon odağı, hastanede yatış süresi, kültür sonuçları, verilen körleme tedavi, tedavi değişikliği ve nedeni, izlem sonuçları, ek tedavi gereksinimi hakkında veriler kayda alındı.

Mutlak nötrofil sayısının 500/ $\mathrm{mm}^{3}$ 'ün altında olduğu veya $500-1000 / \mathrm{mm}^{3}$ arasında olup, takip eden $24-48$ saat içinde $500 / \mathrm{mm}^{3}$ 'ün altına düşme intimali yüksek olan hastalar nötropenik olarak belirlendi.
Bir kez koltuk altı $38,5^{\circ} \mathrm{C}$ 'nin üzerinde veya dört saat arayla iki kez $38^{\circ} \mathrm{C}$ ateşi olan nötropenik olgular febril nötropeni olarak tanımlandı. Aynı hastanın farklı zamanlardaki febril nötropeni atakları, farklı süreç olarak değerlendirildi.

Febril nötropeni atakları üç ana bölümde sınıflandırıldı: 1) Klinik olarak kanıtlanmış enfeksiyon, 2) Mikrobiyolojik olarak kanıtlanmış enfeksiyon, 3) Nedeni bulunamayan ateş.

Çalışmaya alınan hastaların tanılarına göre febril nötropeni atakları ve bakteriyemi açısından risk oluşturabilecek etkenler değerlendirildi. Bu amaçla hastaneye yatış anındaki MNS, MMS değerlerine ve bakteriyemi ile ilişkilerine bakıldı. Saptanabilen enfeksiyon odağının bakteriyemi ile ilişkisi incelendi. Alınan kültürlerde üreyen etkenlerin dağılımları ve tedavide kullanılan antibiyotik rejimleri değerlendirildi. Hastalar tanı ve kemoterapi yoğunluğunun benzerliğine göre gruplandırılarak febril nötropeni sırasındaki ateş süreleri, nötropeni süreleri ve kemoterapi sonrası geçen süre gruplar arasında karşılaştırıldı.

Çalışmaya başlanmadan önce "Uludağ Üniversitesi Tıp Fakültesi Etik Kurul" onayı alındı.

\section{İstatistik}

Değişkenler arasındaki ilişkiler (SPSS 13,0 istatistik programı kullanılarak) incelendi. Kategorik değişken sıklıkları arasındaki farklar ki-kare testi ile araştırıldı. Sürekli değişkenler için iki grup arasındaki dağılım student's t testi, normal dağılım göstermeyenlerde Mann-Whitney U testi ile karşılaştırıldı. Bağımlı iki grup karşılaştırmasında ise Wilcoxon testi ve bağımlı örneklem t testi kullanıldı. İkiden fazla grupların karşılaştırmasında ise tek yönlü varyans analizi veya Kruskal Wallis testi kullanıldı. Değişkenler arasındaki ilişkiler Pearson korelasyon ve Spearman korelasyon katsayıları kullanılarak hesaplandı. Kategorik veriler sıklık ve yüzde (n, \%); sürekli değer alan değişken verileri ise ortalama \pm standart sapma (SS) olarak ifade edildi. Anlamlılık düzeyi, $\alpha=0,05$ $(p<0,05)$ alındı.

\section{Bulgular}

Çalışmamızda 01.01.2000-31.12.2005 tarihleri arasında febril nötropeni tanısı ile hastaneye yatırılan 10 ay-18 yaşları arasında (ortalama 8,8 4 4,3 yıl), 15'i kı $(\% 26,3)$ ve 42'si erkek $(\% 73,7) 57$ hastada gelişen 206 febril nötropeni atağı incelendi. Febril nötropeni ataklarının 155’i $(\% 75,2)$ erkeklerde, 51'i $(\% 21,8)$ kızlarda görüldü. Hasta başına düşen ortalama atak sayısı 3,6 idi. Hastaların tanı ve febril nötropeni ataklarının dağılımları Tablo 1'de özetlendi.

Hastaların yaş gruplarına göre dağılımı ve febril nötropeni atak oranları değerlendirildiğinde: 0-5 yaş grubu $16(\% 28,1)$ hastada 55 (\%26,7) atak; 6-10 yaş grubu $21(\% 36,8)$ hastada $87(\% 42,2)$ atak; 11-15 yaş grubu $14(\% 24,6)$ hastada $47(\% 22,8)$ atak; 16 yaşından büyük altı $(\% 10,5)$ hastada $17(\% 8,3)$ atak saptand.

Hastaların febril nötropeni ataklarında tanı anındaki laboratuvar ve klinik özellikleri Tablo 2'de özetlendi. 
Hastaların başvuru anında yapılan muayenelerine göre, çoğunluğunda $(\% 57,3)$ enfeksiyon odağı saptanmadı. Enfeksiyon odağı saptananlarda sırasıyla farenjit $(\% 14,0)$, mukozit $(\% 12,1)$ ve pnömoni $(\% 7,7)$ tespit edildi (Tablo 3). Santral venöz kateteri olan hasta yoktu.

Çalışmaya alınan atakların 18 'inden $(\% 8,7)$ boğaz sürüntü kültürü gönderildi. On altı kültürde üreme olmadı $(\% 88,9)$. Bir olgunun boğaz sürüntü kültüründe $\mathrm{S}$. aureus kolonizasyonu saptanırken, bir olguda beta hemolitik streptokok üremesi oldu.

Otuz bir atakta (\%15) dışkı kültürü gönderildi. Bunlardan 29 tanesinde $(\% 93,6)$ normal flora, iki hastada $(\% 6,4)$ vankomisin dirençli enterokok (VRE) kolonizasyonu saptandı.

Febril nötropeni ataklarının tümünde idrar kültürü alındı. İdrar kültürlerinin altısında (\%2,9) üreme oldu. Bunlar iki Enterobacter cloaca, iki Enterococcus feacalis, bir Candida albicans ve bir Klebsiella oxytoca idi.

\section{Tablo 1. Febril nötropeni ataklarının hastaların tanılarına göre dağılımı}

\begin{tabular}{|l|c|c|}
\hline Birincil hastalık & $\begin{array}{c}\text { Hasta sayısı } \\
\mathbf{n}(\%)\end{array}$ & $\begin{array}{c}\text { Atak sayısı } \\
\mathbf{n}(\%)\end{array}$ \\
\hline NHL & $15(26.3)$ & $60(29,1)$ \\
\hline Osteosarkom & $8(14)$ & $24(11,7)$ \\
\hline Medülloblastom & $7(12,3)$ & $21(10,2)$ \\
\hline Rabdomiyosarkom & $7(12,3)$ & $33(16)$ \\
\hline Nöroblastom & $6(10,5)$ & $29(14,1)$ \\
\hline Wilms tümörü & $4(7)$ & $11(5,3)$ \\
\hline Ewing sarkomu & $3(5,2)$ & $11(5,3)$ \\
\hline LHH & $3(5,2)$ & $4(1,9)$ \\
\hline Fibrosarkom & $1(1,8)$ & $5(2,4)$ \\
\hline Anjiyosarkom & $1(1,8)$ & $4(1,9)$ \\
\hline PNET & $1(1,8)$ & $3(1,5)$ \\
\hline Ependimom & $1(1,8)$ & $1(0,5)$ \\
\hline Toplam & $57(100)$ & $206(100)$ \\
\hline
\end{tabular}

NHL: Hodgkin dıșı lenfoma; LHH: Langerhans hücreli histiyositoz; PNET: Primitif nöroektodermal tümör

Tablo 2. Hastaların febril nötropeni tanı anındaki özellikleri

\begin{tabular}{|l|c|}
\hline & Ortalama \pm SS (sınırlar) \\
\hline MNS $\left(\mathrm{mm}^{3}\right)$ & $296,5 \pm 342,4(0-1236)$ \\
\hline MLS $\left(\mathrm{mm}^{3}\right)$ & $518,9 \pm 896,7(0-6400)$ \\
\hline MMS $\left(\mathrm{mm}^{3}\right)$ & $144,3 \pm 262,0(0-1580)$ \\
\hline CRP $(\mathrm{mg} / \mathrm{dL})$ & $7,63 \pm 7,06(0-51.6)$ \\
\hline Hemoglobin $(\mathrm{gr} / \mathrm{dL})$ & $8,67 \pm 1,74(4,9-17,4)$ \\
\hline Trombosit $\left(\mathrm{mm}^{3}\right)$ & $121,653 \pm 131,040(2,000-940,000)$ \\
\hline Ateş $\left({ }^{\circ} \mathrm{C}\right)$ & $38,5 \pm 0,2(38,0-39,5)$ \\
\hline Yatış süresi (gün) & $11,4 \pm 4,4(7-36)$ \\
\hline
\end{tabular}

MNS: Mutlak nötrofil sayısı, MLS: Mutlak lenfosit sayısı, MMS: Mutlak monosit sayısI, CRP: C-reaktif protein
Febril nötropeni ataklarının tümünde kan kültürü alındı. Kan kültürlerinin \%14,6'sında üreme saptandı. Gram negatif bakteriyemi oranı \%60 idi. Üreyen etkenler en fazla E. coli $(\% 16,7)$, daha sonra S. epidermidis $(\% 13,3)$ ve Enterobacter cloaca $(\% 13,3)$ idi (Tablo 4).

Febril nötropeni atakları enfeksiyon odağı ve kültür sonuçlarına göre gruplandırıldığında; i) klinik olarak kanıtlanmış enfeksiyon oranı \%42,7 (88 atak); ii) mikrobiyolojik olarak kanıtlanmış enfeksiyon oranı \%17,5 (36 atak); iii) nedeni bulunamayan ateș oranı \%39,8 (82 atak) idi.

Körlemesine tedavide $\% 87,9$ oranında üçüncü kuşak sefalosporin ve aminoglikozid kombinasyonu başlandı (\%71,3 seftazidim ve amikasin, \%16,5 sefepim ve amikasin). Sadece üçüncü kuşak sefalosporin (seftazidim veya sefepim) atakların \%3'ünde, üçüncü kuşak sefalosporinlerin asiklovir, metronidazol, klindamisin gibi diğer ilaçla birlikte tedavisi atakların \%8,7'sinde bașlandı. Karbapenem grubu antibiyotik (meropenem) sadece bir atakta uygulandı.

\section{Tablo 3. Hastaların enfeksiyon odaklarının dağılımı}

\begin{tabular}{|c|c|}
\hline Enfeksiyon odağı & Sayı (\%) \\
\hline Yok & $118(57,3)$ \\
\hline \multicolumn{2}{|l|}{$\operatorname{Var}^{*}$} \\
\hline Farenjit & $29(14,0)$ \\
\hline Mukozit & $25(12,1)$ \\
\hline Pnömoni & $16(7,7)$ \\
\hline Yumuşak doku enfeksiyonu & $8(3,8)$ \\
\hline Akut gastroenterit & $8(3,8)$ \\
\hline Genital dermatit & $4(1,9)$ \\
\hline Herpes labiyalis & $3(1,4)$ \\
\hline Perianal apse & $3(1,4)$ \\
\hline Üriner sistem enfeksiyonu & $3(1,4)$ \\
\hline Suçiçeği & $1(0,4)$ \\
\hline Tiflitis & $1(0,4)$ \\
\hline Otit & $1(0,4)$ \\
\hline
\end{tabular}

${ }^{*}$ Aynı hastada birden fazla odak olabilir

Tablo 4. Kan kültüründe üreyen etkenlerin dağılımı

\begin{tabular}{|l|c|}
\hline Üreyen etkenler & $\begin{array}{c}\text { Sayı (\%) } \\
(\mathbf{n = 3 0 )}\end{array}$ \\
\hline E. coli & $5(16,7)$ \\
\hline Enterobacter cloaca & $4(13,3)$ \\
\hline KNS & $6(20)$ \\
\hline S. pneumoniae & $3(10)$ \\
\hline Acinetobacter baumanii & $3(10)$ \\
\hline Pseudomonas aeroginosa & $3(10)$ \\
\hline C. albicans & $1(3,3)$ \\
\hline S. aureus & $1(3,3)$ \\
\hline Enterococcus raffinosus & $1(3,3)$ \\
\hline Klebsiella pneumonia & $1(3,3)$ \\
\hline Chryseobacterium indologenes & $1(3,3)$ \\
\hline Salmonella enteritidis & $1(3,3)$ \\
\hline
\end{tabular}

KNS: Koagülaz negatif stafilokoklar 
Febril nötropeni ataklarının 139'unda (\%67,5) körlemesine antibiyotik tedavisi değiştirilmedi ve ek ilaç eklenmedi. Körlemesine tedavi başarı oranı \%67,5 olarak saptandı. Körlemesine tedavide seftazidim+amikasin ile başlanan 147 $(\% 71,4)$ atağın 42 'sinde $(\% 28,5)$, sefepim+amikasin ile bașlanan 34 (\%16,5) atağın 11'inde (\%32) tedavi değișikliği gerekti. Körlemesine antibiyotik birlikteliklerinde en fazla eklenen ilaç vankomisin (56 atakta), sonrasında amfoterisin B (15 atakta) ve meropenem ( 9 atakta) idi.

Hastalar tanı ve kemoterapi yoğunluğunun benzerliğine göre dört gruba ayrıldı: Grup 1: Yumuşak doku ve kemik tümörleri, 20 hasta (\%35); grup 2: NHL,15 hasta (\%26.3); grup 3: Nöroblastom ve beyin tümörleri, 15 hasta (\%26.3); grup 4: Wilms tümörü ve langerhans hücreli histiyositoz, yedi hasta (\%12,2).

Tanı gruplarına göre nötropeni süresi, kemoterapi sonrası geçen süre ve ateş süresi karşıllaştııldı. Gruplar arasında ateş sürelerinde istatistiksel olarak anlamlı bir fark saptanmadı ( $p>0,05$ ). Nötropeni sürelerinin karşılaştırımasında, grup 1 ile grup 3 arasında istatistiksel olarak anlamlı fark bulundu $(p<0,05)$. Kemoterapi sonrası geçen süre grup 2'de grup 1 ve grup 3'e göre anlamlı olarak daha kısa saptandı $(\mathrm{p}<0,05)$ (Tablo 5).

Tanı anında bakılan MNS \%45,1 atakta ( $\mathrm{n}=93)$ $100 / \mathrm{mm}^{3}$ 'ün altında, MMS $\% 67,5^{\prime}$ inde $100 / \mathrm{mm}^{3}$ 'ün altında bulundu. Tanı anındaki ortalama CRP bakteriyemi olanlarda

\begin{tabular}{|c|c|c|c|}
\hline Tablo 5. Tanı gruplarına göre nötropeni, ateş ve kemoterapi \\
sonrası geçen süre \\
\hline & $\begin{array}{c}\text { Ateş süresi } \\
\text { (gün) } \\
\text { (ort. } \pm S S \text { ) }\end{array}$ & $\begin{array}{c}\text { Nötropeni süresi } \\
\text { (gün) } \\
\text { (ort. } \pm S S \text { ) }\end{array}$ & $\begin{array}{c}\text { Kemoterapi sonrası } \\
\text { geçen süre (gün) } \\
\text { (ort. } \pm S S \text { ) }\end{array}$ \\
\hline Grup 1 & $3,04 \pm 22$ & $5,8 \pm 2,7^{\mathrm{a}}$ & $6,7 \pm 3,4^{\mathrm{C}}$ \\
\hline Grup 2 & $3,8 \pm 2$ & $6,8 \pm 3,6$ & $5,1 \pm 2,8^{\mathrm{d}}$ \\
\hline Grup 3 & $3,3 \pm 2.3$ & $7,7 \pm 3,2^{\mathrm{b}}$ & $6,8 \pm 3,3 \mathrm{e}$ \\
\hline Grup 4 & $2,5 \pm 1,5$ & $5,9 \pm 2,4$ & $5,9 \pm 2,6$ \\
\hline
\end{tabular}

$a b, c d, d e: p<0,05$

\begin{tabular}{|c|c|c|c|}
\hline \multirow[b]{2}{*}{ Tanı anında } & \multicolumn{2}{|c|}{ Bakteriyemi } & \multirow{2}{*}{ p } \\
\hline & Yok & Var & \\
\hline MNS [n, (\%)] & - & - & - \\
\hline$<100 / \mathrm{mm} 3$ & $82(39,8)$ & $11(5,3)$ & $>0,05$ \\
\hline$\geq 100 / \mathrm{mm} 3$ & $94(45,6)$ & $19(9,2)$ & \\
\hline MMS [n, (\%)] & - & - & - \\
\hline$<100 / \mathrm{mm}^{3}$ & $116(56,3)$ & $23(11,2)$ & $>0,05$ \\
\hline$\geq 100 / \mathrm{mm}^{3}$ & $60(29,1)$ & $7(3,4)$ & \\
\hline CRP [(mg/dl), (ort.. $\pm \mathrm{SD})]$ & $7,26 \pm 6,57$ & $9,80 \pm 9,27$ & $>0,05$ \\
\hline Ateș [( $\left[{ }^{\circ} \mathrm{C}\right),($ ort. $\left.\pm S D)\right]$ & $38,5 \pm 0,2$ & $38,6 \pm 0,3$ & $>0,05$ \\
\hline Enfeksiyon odağı [n, (\%)] & - & - & - \\
\hline Yok & $101(49)$ & $17(8,3)$ & $>0,05$ \\
\hline Var & $75(36,4)$ & $13(6,3)$ & \\
\hline
\end{tabular}

MNS: Mutlak nötrofil sayısı, MMS: Mutlak monosit sayısı, CRP: c-reaktif protein
$9,80 \pm 9,27 \mathrm{mg} / \mathrm{dL}$, olmayanlarda $7,26 \pm 6,57 \mathrm{mg} / \mathrm{dL}$, ortalama ateş bakteriyemi olanlarda $38,6 \pm 0,3^{\circ} \mathrm{C}$, olmayanlarda $38,5 \pm 0,2^{\circ} \mathrm{C}$ saptandı. Enfeksiyon odağı bakteriyemisi olanların \%6,3'ünde, bakteriyemisi olmayanların \%36,4'ünde saptandı. Tanı anındaki MNS, MMS, CRP, enfeksiyon odağı ve ortalama ateș ile bakteriyemi arasında istatistiksel olarak anlamlı ilişki saptanmadı (Tablo 6).

Hastaların ortalama yatış süreleri $11,4 \pm 4,4$ gün, ateş yüksekliği süresi $3,3 \pm 2,8$ gün olarak bulundu. Hastaların almakta oldukları antibiyotik düzenlemeleri ile hastanede yatış süreleri arasında istatistiksel olarak anlamlı bir fark saptanmadı $(p=0,26)$. Mukoziti olan hastalarda (\%13) ortalama yatış süresi $13,2 \pm 4,1$ gün, olmayanlarda (\%87) ortalama yatış süresi $11,1 \pm 4,4$ gün saptandı. Mukozit varığııın yatış süresini anlamlı olarak uzattığı görüldü $(p=0,028)$.

Atakların 42'sinde $(\% 20,4)$ granülosit-koloni stimulan faktör (G-CSF) kullanıldı.

Febril nötropeni ataklarının \%98,6'sı (203 atak) iyileşme ile sonuçlandı, üç hasta kaybedildi. Kaybedilen bu üç hasta (iki osteosarkom, bir nöroblastom) remisyonda olmayan hastalardı. Bu hastalardan nöroblastom tanılı hastanın kan kültüründe K.pneumoniae üremesi oldu, diğer iki hastada kültür üremesi gözlenmedi.

\section{Tartışma}

Çocukluk çağı kanserlerinde uygulanan yoğun kemoterapi kurallarının etkisiyle enfeksiyonlar önemli hastalanma ve ölüm nedeni olmaya devam etmektedir. Körlemesine antimikrobiyal tedavinin temel ilkeleri belirlenmiştir, ancak her merkezde değişebilen etkenler, direnç oranları ve hasta özelliklerine göre farklı kurallar uygulanmaktadır. Tedavi yaklaşımlarındaki gelişmeler ile günümüzde enfeksiyonla ilişkili ölüm oranları erişkinlerde \%4-6, çocuklarda \%1-2'ye kadar gerilemiş̧ir. Ancak yüksek riskli hasta gruplarında enfeksiyonla ilişkili ölüm oranları biraz daha yüksektir $(10,11)$.

Çalışmamızda enfeksiyon etkenlerinin üretilme oranı $\% 17,5$ idi. Gram negatif bakteriyemi oranı $(\% 66,6)$ daha fazla saptandı. Kan kültüründe mantar üremesi olmadı. Enfeksiyondan sorumlu etkenler hastanelere ve aynı hastanenin farklı bölümlerine göre farklılık gösterebilir, ayrıca etkenler zamanla değişebilir. Etkenlerin üretilmesi güçtür ve yaklaşık üçte biri gösterilebilmektedir. Sıklıkla saptanan etkenler KNS, S.aureus, P.aeruginosa, E.coli ve K.pneumoniae'dir (12-17). Geçmiş yıllarda gram negatif etkenler daha fazla saptanmakta iken son yıllarda gram pozitif etkenler ön plandadır. Bodey ve ark.'ları (18) 1966-1972 yılları arasında lösemili hastalarda gram negatif etkenlerin $\% 70$, gram pozitif etkenlerin \%6 oranında görüldüğünü belirtmişlerdir. Sekiz yüz altmış üç febril nötropeni atağınının incelendiği bir çalışmada kan kültüründe üreme oranı $\% 13$, üremelerdeki gram pozitif bakteriyemi oranı $\% 47$ 
saptanmıştır (19). İki yüz altmış yedi febril nötropeni atağının değerlendirildiği başka bir çalışmada gram negatif bakteriyemi oranı \%88,6 saptanmıştır (20). Ülkemizde Düzova ve ark.'ları (14) tarafından yapılan bir çalışmada gram pozitif bakteriyemi oranı \%67 oranında bildirilmiştir. Yakın zamanda yapılan diğer bir çalışmada ise gram negatif bakteriyemi oranı daha yüksek saptanmıştır (2). Febril nötropeni ataklarında gram pozitif bakterilerin daha çok rol oynamasının nedenleri; yoğun kemoterapi sonrası ciddi mukozitlerin gelişmesi, nötropeni ataklarının ağır ve uzun süreli olması, kalıcı damar içi kateterlerin uzun süre kullanımı, H2 reseptör antagonistlerinin, trimetoprim-sülfometoksazol veya kinolon koruyucu tedavisinin kullanımı olarak bildirilmiştir (6). Çalışmamızda gram pozitif bakteriyemi oranının gram negatif bakteriyemiden düşük olmasının hastalarımızda santral venöz kateter kullanılmaması ile ilgili olduğu düşünüldü.

Nötropeninin şiddeti ve süresi enfeksiyon riskini belirlemektedir. Uzamış nötropenisi olan, kemik iliği transplantasyonu yapılan hastalar komplikasyon açısından yüksek risk altındadırlar. Birçok çalışmada onkolojik hastalı̆ın remisyonda olmaması da risk etmeni olarak sayılmaktadır. Yüksek doz ARA-C içeren kemoterapi rejimleri özellikle S.viridans ve mantar enfeksiyonları açısından yüksek enfeksiyöz ölüm oranı ile ilişkili bulunmuştur $(21,22)$.

Hastalarımızın tanıdaki MNS ve MMS ile bakteriyemi arasında istatistiksel olarak anlamlı bir ilişki saptanmadı ( $p>0,05)$. Bazı çalışmalarda MMS'nin MNS'ye göre risk belirleme açısından daha iyi bir gösterge olduğu bildirilmiştir $(9,22)$. Lucas ve ark.'Iarı (23) 509 febril nötropeni atağını incelemiş ve MNS değerinin $100 / \mathrm{mm}^{3}$ 'ün altında olmasının riski arttırdığını saptamışlardır. Başka bir çalışmada düşük riskli febril nötropeni ataklarında MMS $100 / \mathrm{mm}^{3}$ 'ün üzerinde olanlarda bakteriyemi oranının çok düşük olduğu bildirilmiştir (22). Ülkemizde yapılan bir çalışmada ise febril nötropenide lenfopeninin monositopeniden daha erken bir belirteç olduğu saptanmıştır (24).

İki yüz yetmiş beş hastada yapılan bir çalışmada kemoterapi yoğunluğu ile ilişkili olarak osteosarkom ve Ewing sarkomu tanılı hastalarda febril nötropeni sıklığı yüksek, buna karşılık Wilms tümörü ve merkezi sinir sistemi tümörü olan hastalarda düşük olarak saptanmıştır (25). Çalışmamızda kemoterapi yoğunluklarına göre hastalar gruplandırıldığında nötropeni süresi, kemoterapinin daha yoğun olduğu nöroblastom ve beyin tümörleri grubunda, yumuşak doku ve kemik tümörlerine göre daha uzun saptandı $(p<0,05)$. Hasta başına düşen febril nötropeni atak sayısı en fazla nöroblastom grubunda gözlendi.

Yapılan çalışmalarda febril nötropenili hastalarda enfeksiyon odaklarının sıklıkla sindirim sistemi, akciğer ve deri olduğu saptanmıştır $(11,21)$. Erişkin ve çocuk hastaların karşılaştıııldığı 3080 hastada yapılan bir çalışmada enfeksiyon odağı çocuklarda erişkine oranla daha az saptanmış ancak saptanabilen en sık enfeksiyon odağının üst solunum yolu olduğu bildirilmiştir (26). Çalışmamızın sonuçları bu çalışmayı desteklemektedir. Saptayabildiğimiz odaklar sıklık sırasına göre farenjit, mukozit, pnömoni ve yumuşak doku enfeksiyonuydu. Saptanan enfeksiyon odakları ile bakteriyemi arasında istatistiksel olarak anlamlı bir ilişki bulunmadı ancak farenjit ve pnömonisi olan hastalarda bakteriyemi oranı daha yüksekti.

Febril nötropenili hastalarda enfeksiyon hızı ilerleyebileceği için erken dönemde tedavi başlanması uygundur. Üçüncü veya dördüncü kuşak sefalosporinler (sefepim, seftazidim vb.), karbapenemler (meropenem veya imipenem) ve piperasilin-tazobaktam monoterapide kullanılabilecek antibiyotiklerdir. Pseudomonas açısından risk taşıyan hastalarda tekli tedavi uygun değildir. Aminoglikozid ve psödomonasa karşı etkili karboksipenisilin/üreidopenisilin; aminoglikozid ve psödomonasa karşı etkili sefalosporin; aminoglikozid ve karbapenem birliktelikleri en sık kullanılan birlikteliklerdir. Birden fazla antibiyotiğin birlikte kullanılmasının sinerjik etki, direnç gelişiminin önlenmesi gibi üstünlüklerine karşın, sisplatin, siklosporin, amfoterisin B gibi nefrotoksik ilaç kullananlarda aminoglikozidlere bağlı nefrotoksisite, ototoksisite benzeri yan etkilerin artması gibi önemli sakıncaları vardır (8). Genel olarak tedavi yanıtı \%50-70 arasında değișmektedir ve genel sağ kalım oranı \%90'ların üzerindedir (14-16). Kebudi ve ark.'larının (27) sefepim ve seftazidim tekli tedavisinin etkinliğini karşılaştırdıkları ve febril nötropenili çocuklarda yayınlanan ilk uluslararası çalışma özelliği olan çalışmada etkinliğin benzer olduğu saptanmıştır. Başka bir çalışmada 120 febril nötropeni atağında sefepim ve seftazidim tekli tedavisi karşılaştııılış ve sefepimin seftazidime göre daha etkili ve güvenli bulunmuştur (28). Son yıllardaki birçok çalışmada karbapenemler, piperasilin-tazobaktam ve sefepim tedavileri karşılaştııımış ve başarı oranı benzer bulunmuştur $(2,13,15,16)$. Çalışmamızda, febril nötropeni ataklarının \%71,4'ünde körlemesine tedavide seftazidim ve amikasin, \%16,5'inde sefepim ve amikasin tedavisi başlandı. Bu tedaviler arasında etkinlik açısından anlamlı farklılık saptanmadı. Körlemesine tedavi başarı oranımız \%67,5 idi. Ölüm oranımız $(\% 1,45)$ düşük olarak bulundu. Kaybedilen hastalardan ikisi remisyonda olmayan hastalardı ve sadece birinde mikrobiyolojik olarak gösterilmiş enfeksiyon mevcuttu. Yüz dört febril nötropeni atağının incelendiği geçmiş yıllarda yapılan bir çalışmada ölüm oranı yüksek (\%20) olarak bildirilmiştir (29). Ancak özellikle son yıllarda yapılan çalışmalarda ölüm gözlenmemiştir $(15,16,27)$.

Sonuç olarak; 206 febril nötropeni atağının incelendiği çalışmamızda; MNS, MMS, CRP ve ateş ile bakteriyemi arasında istatistiksel olarak anlamlı bir ilişki saptanmadı. Mukozit varlığının hastanede yatış süresini anlamlı olarak uzattığı görüldü. Çalışmamızda gram negatif bakteriyemi daha fazla oranda saptandı. Körlemesine tedavide başarı oranı yüksek ve ölüm oranımız düşüktü. 


\section{Kaynaklar}

1. Hughes WT, Armstrong D, Bodey GP, et al. 2002 guidelines for the use of antimicrobial agents in neutropenic patients with cancer. Clin Infect Dis 2002; 34: 730-51.

2. Uygun V, Karasu GT, Ogunc D, Yesilipek A, Hazar V. Piperacillin/tazobactam versus cefepime for the empirical treatment of pediatric cancer patients with neutropenia and fever: a randomized and open-label study. Pediatr Blood Cancer 2009; 53: 610-4.

3. Sigurdardottir K, Digranes A, Harthug S, et al. A multi-centre prospective study of febrile neutropenia in Norway: Microbiological findings and antimicrobial susceptibility. Scand J Infect Dis 2005; 37: 455-64.

4. Kebudi R. Diagnosis and Treatment of Febrile Neutropenia in children \& studies conducted in Turkey. Turkiye Klinikleri $\mathrm{J}$ Pediatr Sci 2009; 5: 145-56.

5. Sarıbeyoglu ET, Akçay A. Febrile neutropenia in pediatric hematology and oncology: descriptions and management. Turkiye Klinikleri J Pediatr Sci 2009; 5: 120-30.

6. Celkan T, Diren S, Özyılmaz İ, et al. The growth rates, isolated agents and their antibiotic resistance in febrile neutropenic attacs between 2000-2004 years. ANKEM Derg 2006; 20: 4-9.

7. Greenberg D, Moser A, Yagupsky $P$, et al. Microbiological spectrum and susceptibility patterns of pathogens causing bacteraemia in pediatric febrile neutropenic oncology patients: comparison between two consecutive time periods with use of different antibiotic treatment protocols. Int $\mathrm{J}$ Antimicrob Agents 2005; 25: 469-73.

8. Sipsas NV, Bodey GP, Kontoyiannis DP. Perspectives for the management of febrile neutropenic patients with cancer in the 21st century. Cancer 2005; 103: 1103-13.

9. Viscoli C, Varnier O, Machetti M. Infections in patients with febrile neutropenia: epidemiology, microbiology, and risk stratification. Clin Infect Dis 2005; 40: 240-5.

10. Klaassen RJ, Goodman TR, Phan B, Doyle JJ. "Low-risk" prediction rule for pediatric oncology patients presenting with fever and neutropenia. J Clin Oncol 2000; 18: 1012-9.

11. Tezcan G, Küpesiz A, Öztürk F, et al. Episodes of fever and neutropenia in children with cancer in a tertiary care medical center in Turkey. Pediatr Hematol Oncol 2006; 23: 217-29.

12. Lai HP, Hsueh PR, Chen YC, et al. Bacteremia in hematological and oncological children with febrile neutropenia: Experience in a tertiary medical center in Taiwan. J Microbiol Immunol Infect 2003; 36: 197-202.

13. Aksoylar S, Çetingül N, Kantar M, Karapinar D, Kavakli K Kansoy S. Meropenem plus amikasin versus piperacillintazobactam plus netilmicin as empiric therapy for high-risk febrile neutropenia in children. Pediatr Hematol Oncol 2004; 21: 115-23.

14. Düzova A, Kutluk T, Kanra G, et al. Monotherapy with meropenem versus combination therapy with piperacillin plus amikacin as empiric therapy for neutropenic fever in children with lymphoma and solid tumors. Turk J Pediatr 2001; 43: 105-9.
15. Yildirim I, Aytac S, Ceyhan M, et al. Piperacillin/tazobactam plus amikacin versus carbapenem monotherapy as empirical treatment of febrile neutropenia in childhood hemotological malignancies. Pediatr Hematol Oncol 2008; 25: 291-9.

16. Corapcioglu F, Sarper N, Zengin E. Monotherapy with piperacillin/tazobactam versus cefepime as empirical therapy for febrile neutropenia in pediatric cancer patients: a randomized comparison. Pediatr Hematol Oncol 2006; 23: 177-86.

17. Santolaya ME, Alvarez AM, Becker A, et al. Prospective, multicenter evaluation of risk factors associated with invasive bacterial infection in children with cancer, neutropenia, and fever. J Clin Oncol 2001; 19: 3415-21.

18. Bodey GP, Rodriguez V, Chang HY, Narboni. Fever and infection in leukemic patients: A study of 494 consecutive patients. Cancer 1978; 41:1610-22.

19. Paganini H, Bologna R, Debbag R, et al. Fever and neutropenia in children with cancer in one pediatric hospital in Argentina. Pediatr Hematol Oncol 1998; 15:405-13.

20. Chayakulkeeree M, Thamlikitkul V. Risk index for predicting complications and prognosis in Thai patients with neutropenia and fever. J Med Assoc Thai 2003; 86: 212-23.

21. Crawford J, Dale DC, Lyman GH. Chemotherapy-induced neutropenia: risk, consequences, and new directions for its management. Cancer 2004; 100: 228-37.

22. Orudjev E, Lange BJ. Evolving concepts of management of febrile neutropenia in children with cancer. Med Pediatr Oncol 2002; 39: 77-85.

23. Lucas KG, Brown AE, Armstrong D, Chapman D, Heler G. The identification of febrile, neutropenic children with neoplastic disease at low risk for bacteremia and complications of sepsis. Cancer 1996; 77: 791-8.

24. Oguz A, Karadeniz C, Citak EC, Cil V. Which one is a risk factor for chemotherapy-induced febrile neutropenia in childhood solid tumors: Early lymphopenia or monocytopenia? Pediatr Hematol Oncol 2006; 23: 143-51.

25. Viden $\mathrm{HH}$, Grundy PE, Robinson JL. Early discontinuation of intravenous antimicrobial therapy in pediatric oncology patients with febrile neutropenia. BMC Pediatr 2005; 5: 1-6.

26. Hann I, Viscoli C, Paesmans M, Gaya M, Glauser M. A comparison of outcome from febrile neutropenic episodes in children compared with adults: results from four EORTC studies. International Antimicrobial Therapy Cooperative Group (IATCG) of the European Organization for Research and Treatment of Cancer (EORTC). Br J Haematol 1997; 99: 580-8.

27. Kebudi R, Görgün O, Ayan I, Gürler N, Akici F, Töreci K. Randomized comparison of cefepime versus ceftazidime monotherapy for fever and neutropenia in children with solid tumors. Med Pediatr Oncol 2001; 36: 434-41.

28. Chuang YY, Hung IJ, Yang CP, Jaing TH, Lin TY, Huang YC. Cefepime versus ceftazidime as empiric monotherapy for fever and neutropenia in children with cancer. Pediatr Infect Dis J 2002; 21: 203-9.

29. Rogiun A, Kasis I, Ben-Arush MW, Sharon R, Berant M. Fever and neutropenia in children with malignant disease. Pediatr Hematol Oncol 1996; 13: 503-10. 